\title{
Lesson/Learning Studies and Mathematics Education
}

\author{
Marisa Quaresma and Carl Winsløw
}

Lesson Study (Shimizu, 2014) and Learning Study (Runesson, 2014) (LS) have a growing importance in pre- and in-service mathematics teacher education, and are increasingly objects and methods of research in mathematics education. Many social, cultural, cognitive, and affective issues influence the way Lesson Study/Learning Study develops, and its outcome (Ponte et al., 2014). Research into these issues generates a quest for more solid theorization of the lesson-study process (e.g., Clivaz, 2015; Miyakawa \& Winsløw, 2009). Both practice and research were focused on in this Discussion Group.

Both sessions were opened by short interventions by invited members of a panel (different for the two sessions) followed by questions and a general discussion led by a discussant.

The first session focused on regional/national particularities of and approaches to Lesson Study/Learning Study in mathematics education around the world. The panel members were Takuya Baba (Japan), Lim Chap Sam (Malaysia), Aoibhinn Ní Shúilleabháin (Ireland), and João Pedro da Ponte (Portugal), and the discussant was Stéphane Clivaz (Switzerland). Each of the panelists presented observations and questions from their experience with LS in their respective countries. In Japan, the use of LS has more than 100 years of history and is common in primary and lower secondary schools. In some countries outside Japan, many schools have become involved in LS, but in all countries it remains a major challenge to make LS "sustainable" in the sense that it can continue as a teacher-led activity without special funds or aid from outside. The rationales and effects of LS were also discussed; it was emphasized that the ultimate goal of LS is to further students' learning, even if this passes through teachers' learning.

The second session had theoretical, methodological and epistemological issues as its theme. The panel members were Toshiakira Fujii (Japan), Stéphane Clivaz

\footnotetext{
M. Quaresma ( $\bowtie)$

Instituto de Educação, Universidade de Lisboa, Lisboa, Portugal

e-mail: mq@campus.ul.pt

(C) The Author(s) 2017

G. Kaiser (ed.), Proceedings of the 13th International Congress on Mathematical

Education, ICME-13 Monographs, DOI 10.1007/978-3-319-62597-3_102
} 
(Switzerland), Klaus Rasmussen (Denmark), María Soledad Estrella (Chile), and Akihiko Takahashi (USA), and Takuya Baba led the discussion. The main topics raised were ethical aspects of "repeats of lessons," which seem to be favored by some proponents of LS; recent theoretical developments in didactical research on $\mathrm{LS}$; the roles and interaction of teachers and researchers in LS; and the use of new technology (such as the Lesson Note app). The crosscutting issue was what the key elements of LS are and which of these can and cannot be adapted to different contexts.

\section{References}

Clivaz, S. (2015). French Didactique des Mathématiques and Lesson Study: A profitable dialogue? International Journal for Lesson and Learning Studies, 4(3), 245-260.

Miyakawa, T., \& Winsløw, C. (2009). Didactical designs for students' proportional reasoning: An "open approach" lesson and a "fundamental situation". Educational Studies in Mathematics, 72(2), 199-218.

Ponte, J. P., Quaresma, M., Baptista, M., \& Mata-Pereira, J. (2014). Teachers' involvement and learning in a lesson study. In S. Carreira, N. Amado, K. Jones, \& H. Jacinto (Eds.), Proceedings of the problem at web international conference: Technology, creativity and affect in mathematical problem solving (pp. 321-333). Portugal: Faro.

Runesson, U. (2014). Learning study in mathematics education. In S. Lerman (Ed.), Encyclopedia of mathematics education (pp. 356-358). Netherlands: Springer.

Shimizu, Y. (2014). Lesson study in mathematics education. In S. Lerman (Ed.), Encyclopedia of mathematics education (pp. 358-360). Netherlands: Springer.

Open Access Except where otherwise noted, this chapter is licensed under a Creative Commons Attribution 4.0 International License. To view a copy of this license, visit http://creativecommons. org/licenses/by/4.0/.

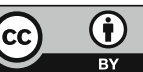

